\title{
The role of extracurricular activities in foreign language teaching
}

\author{
Nasiba NORMURODOVA ${ }^{1}$, Charos URALOVA ${ }^{2}$, Parvina OLIMZODA ${ }^{3}$ \\ Samarkand State Medical Institute \\ Samarkand State Institute of Foreign Languages
}

\begin{tabular}{l} 
ARTICLE INFO \\
\hline Artidehistory; \\
Received April 2021 \\
Received in revised form \\
20 April 2021 \\
Accepted 15 May 2021 \\
Available online \\
25 June 2021
\end{tabular}

\section{Keywords:}

academic,

athletic,

community service clubs,

performanceorganizations,

cheerleading clubs,

social fraternity,

sorority,

volunteering.

\begin{abstract}
Methods of organizing and conducting extracurricular activities in a foreign language issues have not yet been fully explored. Textbooks and manuals on these issues do not adequately cover the methods of organizing and conducting evenings and competitions. This scientific article examines the methods of organizing and conducting evenings in a foreign language, and general concepts of extracurricular activities, methods of conducting song evenings, methods of conducting science and technical news evenings. In addition, the methodology of organizing and conducting competitions and quizzes, including the methodology of organizing and conducting oral speech skills competitions will be studied in depth.
\end{abstract}

2181-1415/C 2021 in Science LLC.

This is an open access article under the Attribution 4.0 International (CC BY 4.0) license (https://creativecommons.org/licenses/by/4.0/deed.ru)

\section{Xorijiy tillarni o'qitishda darsdan tashqari mashg'ulotlarning roli}

Kalitso'zlar:
akademik,
sport,
jamoatxizmatlari klublari,
chiqishlarni tashkil etish, qo'llab-
quvvatlash klublari, ijtimoiy
birodarlik,
ayollarjamiyati,
ko'ngillilik.

\begin{abstract}
ANNOTATSIYA
Chet tili masalalarida sinfdan tashqari ishlarni tashkil etish va o'tkazish usullari hali to'liq o'rganilmagan. Ushbu masalalar bo'yicha darsliklar va o'quv qo'llanmalarida kechalar va musobaqalarni tashkil etish va o'tkazish usullari yetarli darajada yoritilmagan. Ushbu ilmiy maqolada chet tilida oqshomlarni tashkil etish va o'tkazish usullari va sinfdan tashqari ishlarning umumiy tushunchalari, qo'shiq kechalarini o'tkazish usullari, ilmiy va texnik yangiliklar kechalarini o'tkazish usullari ko'rib chiqilgan. Bundan tashqari, musobaqalar va viktorinalarni tashkil etish va o'tkazish metodikasi, shu jumladan og'zaki nutq mahorati musobaqalarini tashkil etish va o'tkazish metodikasi chuqur o'rganiladi.
\end{abstract}

\footnotetext{
${ }^{1}$ Lecturer, Samarkand State Medical Institute. Samarkand, Uzbekistan.

E-mail: normuradova74@gmail.com.

2 Student, Samarkand State Institute of Foreign Languages. Samarkand, Uzbekistan.

E-mail: charosuralova99@gmail.com.

${ }^{3}$ Lecturer, Samarkand State Medical Institute. Samarkand, Uzbekistan.

E-mail: p.olimzoda29@gmail.com.
} 


\section{Роль дополнительных занятий в обучении иностранному языку}

\author{
Ключевые слова: \\ академические, \\ спортивные, \\ общественные клубы, \\ организации \\ выступлений, \\ клубы поддержки, \\ социальное братство, \\ женское общество, \\ волонтерство.
}

\begin{abstract}
АННОТАЦИЯ
Методы организации и проведения внеклассных занятий по вопросам иностранного языка до сих пор полностью не изучены. Учебники и пособия по этим вопросам недостаточно освещают методы организации и проведения вечеров и конкурсов. В данной научной статье рассматриваются методы организации и проведения вечеров на иностранном языке, а также общие концепции внеклассной деятельности, методы проведения песенных вечеров, методы проведения вечеров научно-технических новостей. Кроме того, будет углубленно изучена методика организации и проведения конкурсов и викторин, в том числе методология организации и проведения конкурсов устной речи.
\end{abstract}

\section{INTRODUCTION}

Extracurricular or extra academic activities refer to those activities which took place outside the realm of the normal curriculum of education. The term appeared in the 19th century in European and North American schools and universities though some examples of extracurricular activities such as competitions and drama dated back to ancient Athens and Sparta [1]. Extracurricular activities are used today to improve students communicative, social and artistic skills [2]. They are usually conducted under supervision of educators to guide students towards a particular behavior or a skill. Researchers [3] argued that extracurricular activities are necessary for the appropriate growth of students and for the improvement of their self-confidence, intelligence and personality.

The main examples of extracurricular activities which have received interest from researchers are: academic, athletic, community service clubs, performance organizations, cheerleading clubs, social fraternity, sorority and volunteering [4]. There is generally-accepted definition of the term ECA, and whenever researchers attempt to define it, they describe it in the form of examples of activities [5]. Some researchers even use synonyms such as out-of-class experiences to describe extracurricular activities [6].

All the educationists and educators have realized the importance of extracurricular activities in academic life. These activities keep students refreshed both physically and mentally. Students can learn time management with help of these activities can make students wiser in managing their time. They also learn multitasking through it. The team spirit in the students also enhances with these activities. These ECA can help language learners to find out their interests. When they get opportunity to choose from a number of ECA, they come to access which activity are they most interested and comfortableare.

Extracurricular activities in foreign languages, as well as other subjects, are an integral part of the general educational process. In the context of education reform, the importance of extracurricular activities has increased significantly. The experience of advanced foreign language teachers shows that properly organized classroom and extracurricular activities help to improve the quality of students' language skills. Increase their practical skills and abilities. Also it increases their creative activity, initiative, and ultimately helps to nurture our spiritual values in a spirit of deep respect for labor. Nowadays, no one can recognize how important and necessary it is to conduct various extracurricular activities in a foreign language with students. In recent years, the methodological literature has 
published a number of articles and collections in the field of extracurricular activities of students and advanced experience of students in foreign languages.

Developing the individual characteristics of students is undoubtedly one of the most important tasks of extracurricular activities. However, working with students who are particularly interested in learning a foreign language is poorly covered in the methodological literature, and students face difficulties in choosing organizational forms of working with such students. Therefore, these problems can be solved by being aware of the innovations in the experience and methodology of teachers.

When conducting extracurricular activities with students, the teacher solves the general educational and pedagogical situations, as well as the situations facing the lessons. However, the nature of extracurricular and out-of-school work makes it possible to identify the specific tasks facing the student. First of all, the lack of interest and strict programming requirements for students' voluntary participation in this work allows the teacher to create a wider environment in the classroom than any other language environment that enhances students' speaking skills. Conversations with foreign tourists, volunteers, communication with people who have traveled abroad, or who are fluent in a foreign language, or strict participation in meeting nights, watching non-dubbed movies, cartoons and other similar forms of language communication for students practical use as a tool provides an understanding of how valuable the skills and competencies generated in the lessons are. All this creates a particularly favorable environment for the development of language skills and competencies created in the classroom. Therefore, the further development and automation of students' oral and reading skills, as well as their skills in the process of learning a foreign language in the classroom, should be considered as a key aspect of extracurricular activities. Certain freedom in the choice of materials and form of work expands the general level of knowledge of students, creates favorable conditions for their upbringing. Indeed, the extensive use of materials in newspapers and magazines that cover the daily life of the country where the language is studied provides an in-depth and thorough acquaintance with the modern life of these countries, educating students in the spirit of patriotism. Extracurricular activities in foreign languages in the aesthetic education of students are much more helpful than in-class activities. When it comes to choosing the right texts for plays, songs, poems for extracurricular evenings in a foreign language, it is a little easier to nurture a love of art and beauty in students' lives than in the classroom. The method of spending the nights (stands, showcases. Albums, art music at night) helps in the same way. Extracurricular activities from the classroom, by their very nature, allow for much more consideration of students' individual interests and capabilities. The teacher can assign different tasks to students based on how well they have developed their oral, reading, and writing skills and abilities. This, in turn, provides an opportunity to increase students' interest and inclination to learn the language. Therefore, the main purpose of extracurricular activities is to increase the level of language proficiency in students with a special interest and inclination to learn foreign languages. We will briefly describe what is done in English outside of school and classroom, taking into account the specifics of this work, and move on to consider their content. As mentioned above, the purpose of extracurricular and out-ofschool activities is to improve the skills and competencies in the practical acquisition of language, which is a means of communication, that is, to further develop oral and reading skills.

The issue of the success of the educational process is a problem that has existed in all ages. Reforms and research reflected new forms, methods and content of teaching, thus contributing to the specific structure of education, in particular its practical features. The successful organization of lessons and the choice of successful methods affect the activities of students, the compatibility of teaching materials and methods makes learning and teaching easier, faster, more accurate and more rational. It is precisely the skills of successful preparation and conduct, appropriate procedures, methods, forms of interaction, media and technology that distinguish modernity and openness. Such education leads to a 
quality school and knowledge society, empowers both the individual and the group, and leads to the formation of professional and innovative, humane and socially oriented community members. Using a variety of activities and materials, modern media and teaching strategies in line with the development of global culture and civilization, as well as the creativity of students are encouraged. We can conclude that such opportunities allow Learners to develop comprehensively and continuously improve their personality. Continuing with the trends and intentions of reform directions in modern school pedagogy, it encouraged and supported the opening of schools for the needs of young people and its educational values to expand the extracurricular leisure time of young people. Thus, students are grouped around a variety of activities: music, science, research, and more. This means that the school has provided its students with the opportunity to spend their free time in the quality of extracurricular activities and in the learning environment, individual development for educational purposes.

The success of a modern school is manifested in the establishment of connections between its students, teachers and the content of education; it influences the development of students, enriches their knowledge and develops their skills. We emphasize that the right tools for purposeful student developmentare nothing more than extracurricular activities because they help students organize their free time meaningfully after regular classes. It should also be noted that students independently choose how to spend their free time and what activities to participate in, actively participate in the work and encourage themselves to be innovative and creative. In this way, they develop their personal qualities, acquire knowledge and skills while experiencing, perceiving and evaluating the cultural, scientific, technical and sports achievements of mankind.

They are introduced to the qualitatively and aesthetically valuable achievements of our time, which affect their general knowledge and worldview. In addition, they have a culture of having a good time, not idleness. Extracurricular activities are an effective system in which modern learning objectives can be achieved and learning strategies that facilitate learning are successfully implemented. Through a variety of thematic activities, students will be able to identify, generalize, and identify strategies for differences and similarities, enhance and recognize strengths, practice, review, collaborate, interact, make assumptions, and test. have the ability to use strategies to conduct and formulate questions. Therefore, it is important to raise awareness about the role and value of extracurricular activities and the opportunities they offer, and to encourage their organization and implementation. Extracurricular activities enrich school life, often reflecting the fact that it has a distinctive character.

A system that reflects the planned educational activities carried out in the framework of extracurricular activities. To the teacher, they show an extended educational impact on the school audience. We can look at extracurricular activities from two perspectives: narrower and wider. In a narrow sense, extracurricular activities are part of the school package; regular classes, and a broader perspective depends on the ability to open the school to the general public. A narrower understanding of school-oriented extracurricular activities is described as extracurricular activities cover a variety of activities that students engage in and out of school, but the curriculum outside the plan and regular curriculum. It is obvious that the educational work in the school is continued only in the free time of the students and in the implementation of a special work strategy, which is very important.

On the other hand, the school opens its doors to everything around it: other schools, students, teachers, professionals, and unions, thanks to the efforts of the educators, who are the group of stakeholders who run these activities. Given the importance of both education and upbringing in the formation of a modern personality, we note that educational work in extracurricular activities, in addition, creates the opportunity to constantly apply the principles of parenting at work. Although activity leaders need to expend maximum effort, knowledge, patience, and willpower to make a difference in the learner, much depends on the learner as well. The success of educational work is the 
fruit of mutual, cooperative relations. In this sense, the effectiveness of education and training is manifested in the use of the principles of originality in work, respect for differences between students, recognition and satisfaction of basic needs, and the use of different working methods and tools. All of these principles are equally important and useful. It should be noted that a teacher's passion is not sufficient to manage good educational work and extracurricular activities, as it requires strong skills for this work. That is, professional knowledge and methodological training are required. The creative productivity of students depends in many ways on the professional ability of the teacher, his actions, work methods and his relationship with his students. The teacher's knowledge, skills, and experience are promoted in their work of informing, directing, planning, organizing, and conducting extracurricular activities for students.

\section{CONCLUSION}

In conclusion, the students can develop some very useful skills like leadership skills, communication skills, bargaining skills and so on. These skills help learners throughout their lives in leading a successful life. One more thing that students learn from extracurricular activities is to socialize well among people. While performing such activities the students interact with a lot of people which makes them more efficient in socializing.

\section{REFERENCES:}

1. Macarova V., \& Reva A. (2017). Perceived impact of extra-curricular activities on foreign language learning in Canadian and Russian university contexts. Apples Journal of Applied Language Studies, 11(1). - PP. 43-65.

2. Simoncini K., \& Caltabiano N. (2012). Young school-aged children's behavior and their participation in extracurricular activities. Australasian Journal of Early Childhood, 37(3).

3. Holt N.L., Sehn Z.L., Spence J.C., Newton A.S., \& Ball G.D.C. (2012). Physical education and sport programs at an inner city school: Exploring possibilities for positive youth development. Physical Education \& Sport Pedagogy, 17(1). - PP. 97-113. DOI: 10.1080/17408989.2010.548062.

4. Hunt D.H. (2005). The effect of extracurricular activities in the educational process: Influence on academic outcomes. Sociological Spectrum, 25. - PP. 417-445.

5. Nelson I.T., Vendrzyk J.J., Quirin, \& Allen R.D. (2002). No, the sky is not falling: Evidence of accounting student characteristics at FSA schools, 1995-2000. Issues in Accounting Education, 17(3). - PP. 269-287.

6. Bartkus K.R., Nemelka B., Nemelka M., \& Gardner P. (2012). Clarifying The Meaning of Extracurricular Activity: A Literature Review of Definitions. American Journal of Business education, 5(6). - PP. 393-704. 